\title{
EFFECTS OF SHRIMP LITOPENAEUS VANNAMEI (BOONE, 1931) CAGE FARMING ON SEDIMENT NUTRIENTS IN A SUBTROPICAL ESTUARY
}

\author{
PEREIRA, L.A. ${ }^{1}$; VENTURA, R. ${ }^{2}$; PERBICHE-NEVES, G. ${ }^{3}$; SILVA, M.D. ${ }^{4}$; \\ BOEGER, W. ${ }^{4} \&$ OSTRENSKY, A. ${ }^{4}$ \\ 1 - Instituto Federal do Paraná - Paraná. \\ 2 - Empresa de Pesquisa Agropecuária e Extensão Rural e Santa Catarina S.A - (EPAGRI); Centro de \\ Desenvolvimento em Aqüicultura e Pesca (CEDAP). \\ 3 - Departamento de Biologia, SEAA, CEDETEG, Universidade Estadual do Centro Oeste, \\ Guarapuava, PR. \\ 4 - Grupo Integrado de Aquicultura e Estudos Ambientais (GIA); Universidade Federal do Paraná. \\ *Corresponding author: robson.epagri@gmail.com
}

\begin{abstract}
Pereira, L.A.; Ventura, R.; Perbiche-Neves, G.; Silva, M.D.; Boeger, W. \& Ostrensky, A. (2013) Effects of shrimp Litopenaeus vannamei (Boone, 1931) cage farming on sediment nutrients in a subtropical estuary. Braz. J. Aquat. Sci. Technol. 17(2):NB5-8. eISSN 1983-9057. DOI: 10.14210/bjast.v17.n2.pNB5-8 The objective of this study was to evaluate the effects of shrimp (Litopennaeus vannamei) cage farming on sediment nutrients concentration. The farm were located in a subtropical estuary (Guaratuba Bay) in the south of Brazil and held 300 cages (size: $3.6 \mathrm{~m} \times 3.6 \mathrm{~m} \times 2 \mathrm{~m}$ ) made of PVC distributed over an area of approximately $4200 \mathrm{~m}^{2}$. Shrimps were fed with two types of commercial feeds, one developed specifically for shrimp and other for fish. Five sampling points were defined, one was located at the center of the farm area, one was set $1000 \mathrm{~m}$ away from the farm, in an area with similar hydrodynamics conditions, and the others were located $200 \mathrm{~m}$ away from the culture in west, northeast and southwest directions. During one year, monthly sediment sampling was performed at each station. Carbon $(C)$, phosphorus $(P)$, calcium $\left(\mathrm{Ca}^{2}+\right)$, and potassium $(\mathrm{K}+)$ concentrations were determined. The results consistently indicate that in the studied shrimp farm the nutrients concentration increased significantly below the cultivation cages. We also obtained an indication that under the studied conditions the raise in the levels of nutrients can reach distances in the range of $200 \mathrm{~m}$.
\end{abstract}

Keywords: cage farm, environmental impacts, bottom sediments

\section{INTRODUCTION}

Marine shrimp farming has been traditionally performed in ponds. Nevertheless the cultivation in floating cages is an alternative technology that has been tested in different countries (Paquotte et al., 1998; Lombardi et al., 2006; Haward et al., 2007; Zarain-Herzberg et al. 2010). This rearing system presents advantages over traditional farming carried out in ponds. In particular, it demands less investment, does not imply earthmoving, allows energy savings by renewal of water, and does not require expenditures for purchasing land or digging ponds (Paquotte et al., 1998; Wasielesky, 2000).

Despite the advantages associated with this production system, environmental implications of this activity are poorly known, particularly those related to sedimentation of particulate matter and hiper-nutrification of sediment where farming is performed. The objective of this study was to evaluate the effects of shrimp (Litopennaeus vannamei) cage farming on sediment nutrients concentration.

The study was performed during the most extensive Brazilian experience in shrimp cage farming, in a farm located at Guaratuba Bay, state of Parana, Brazil. The bay covers approximately $48 \mathrm{~km}^{2}\left(25^{\circ} 52^{\prime} \mathrm{S}\right.$; $\left.48^{\circ} 39^{\prime} \mathrm{W}\right)$, presenting $15 \%$ of shallow areas with average depth of approximately three meters and maximum depth of 27 meters at its mouth, with maximum tidal range of three meters. Guaratuba Bay is approximately $16 \mathrm{~km}$ long, East-West oriented. The bay is $3 \mathrm{~km}$ wide during low tides and $10 \mathrm{~km}$ wide during high tides, when considering the tidal flats. Its mouth has a $500 \mathrm{~m}$ opening limited by two rocky points. The bay receives freshwater inputs from two major rivers (Cubatão and São João). Their drainage basins cover $1700 \mathrm{~km}^{2}$, and have a flux of $80 \mathrm{~m}^{3}$ of water per second.

The farm held 300 cages (size: $3.6 \mathrm{~m}$ x $3.6 \mathrm{~m} \times$ $2 \mathrm{~m}$ ) made of PVC distributed over an area of approximately $4200 \mathrm{~m}^{2}$. The investigation was carried out between 2002 and 2003, during three culture cycles that lasted $110\left(03 / 06^{\text {th }}\right.$ to $\left.06 / 24^{\text {th }}\right), 107\left(09 / 24^{\text {th }}\right.$ to $\left.01 / 08^{\text {th }}\right)$ and 97 days $\left(01 / 08^{\text {th }}\right.$ to $\left.04 / 14^{\text {th }} / 02\right)$, respectively, with 93 days interval between the first and second cycle. There was no time interval between the second and the third culture cycle. The cages were stocked with $L$. vannamei $\mathrm{PL}_{20}$ (metamorphosis occurred 20 days before stocking), under a density of $720 \mathrm{PL} / \mathrm{m}^{2}$. Shrimps were harvested when they reached an average weight of $10 \mathrm{~g}$.

Shrimps were fed with two types of commercial feeds (Table 1), one developed specifically for shrimp 
Table 1 - Nutritional information on the two types of commercial feed (one developed specifically for shrimps and other for fish) used during the monitored period in the studied Litopenaeus vannamei farm.

\begin{tabular}{ccc}
\hline \hline Parameters & Shrimp feed (\%) & Fish feed (\%) \\
\hline Humidity & 6.61 & 6.06 \\
Crude protein & 36.37 & 41.44 \\
Ethereal Extract & 13.27 & 11.65 \\
Mineral residue & 11.83 & 12.99 \\
Crude fiber & 2.42 & 5.42 \\
Acid Detergent Fiber (ADF) & - & - \\
Neutral Detergent Fiber (NDF) & - & - \\
Nitrogen free extractive (NFE) & 29.46 & 22.44 \\
Calcium & 2.93 & 3.34 \\
Phosphorus & 1.56 & 2 \\
\hline \hline
\end{tabular}

and other for fish. The amount of feed provided was determined based on feeding tables and on visual criteria (ad libitum). An estimate of $78 \mathrm{~kg}$ of feed was used during each culture cycle for each cage, what accounted for $23400 \mathrm{~kg}$ of feed per cycle. Feed was manually provided.

Five sampling points were defined (Figure 1). Point one was located at the center of the farm area while points two, three and four were located $200 \mathrm{~m}$ away from the culture in west, northeast and southwest directions. Point five (control) was set $1000 \mathrm{~m}$ away from the farm, in an area with similar hydrodynamics conditions. During one year, monthly sampling was performed at each station. In August, during the interval between culture cycles, two sampling efforts were performed, totalizing 13 samplings. Three samples of sediment (triplicates) were collected with a Petersen drag during each sampling effort. Chemical analysis of sediment was conducted at Department of Soil and

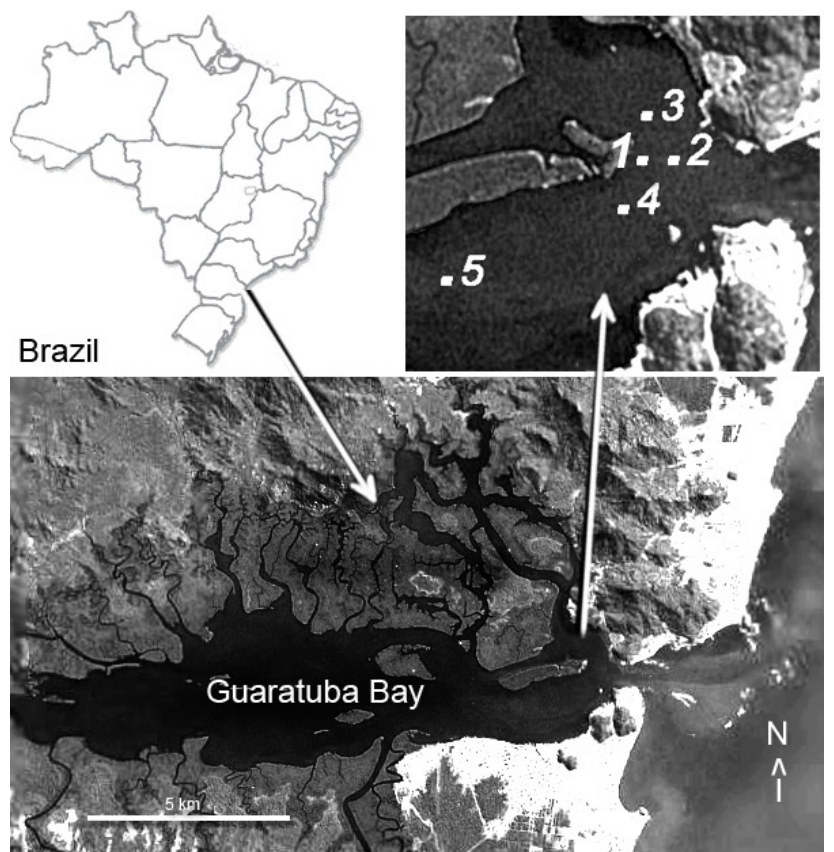

Figure 1 - Location of sampling points. Point one was located at the center of the farm area while points two, three and four were located $200 \mathrm{~m}$ away from the culture, in west, northeast and southwest directions. Point five (control) was located in a site $1,000 \mathrm{~m}$ away from the farm.
Agricultural Engineer of Federal University of Paraná (Curitiba, Brazil). Carbon (C), phosphorus (P), calcium $\left(\mathrm{Ca}^{2+}\right)$, and potassium $\left(\mathrm{K}^{+}\right)$concentrations were determined.

Considering that the generated data deviated significantly from a normal distribution, non-parametric statistics was performed. A Kruskal-Wallis ANOVA test was used to compare results between sampling points and Multiple Comparisons of Means Ranks Test was applied to determine homogeneous groups. The software STATISTICA 7.0 (StatSoft) was used for the analysis.

Final mean survival rate was $60 \%$ and the feed conversion ratio was estimated as 1.3. Concentration of all analyzed nutrients differed significantly among sampling points $(p<0.05)$ (Table 2$)$. Levels of nutrients observed in station two, four and five did not differ significantly and were lower than those observed in station one. Levels observed in station three did not differ significantly from those in station one. When a graph is plotted with data temporally distributed an increase in the levels of nutrients in station one can be observed, especially during the first cultivation cycle. In relation to the station three, the levels seem to have improved by the end of the second and during the third cycle (Figure 2).

The results consistently indicate that in the studied shrimp farm the nutrients concentration increased significantly below the cultivation cages. Our data are consonant with a series of studies on large scale cage farming performed with different species (Islam, 2005). However it differs from the results obtained by Paquotte et al. (1998) which was carried out with shrimp and under conditions similar to this study, although in other region of Brazil (150km south of the city of Salvador). These authors did not observe evidences of accumulation of organic matter below the cages after three years of rearing activities However, it is important

Table 2 - Mean values (minimum and maximum) of sediment chemical analysis $(\mathrm{Ca} 2+, \mathrm{K}+, \mathrm{P}$, and $\mathrm{C})$ at the five sampling points. Point 1 represents culture unities. Superscript letters indicate homogeneous groups.

\begin{tabular}{|c|c|c|c|c|}
\hline Points & $\begin{array}{c}\mathrm{Ca}^{2+} \\
\left(\mathrm{cmol} \cdot \mathrm{dm}^{-3}\right)\end{array}$ & $\begin{array}{c}\mathrm{K}^{+} \\
\left(\mathrm{cmol} \cdot \mathrm{dm}^{-3}\right)\end{array}$ & $\begin{array}{c}\mathrm{P} \\
\left(\mathrm{mg} \cdot \mathrm{dm}^{-3}\right)\end{array}$ & $\begin{array}{c}\mathrm{C} \\
\left(\mathrm{g} \cdot \mathrm{dm}^{-3}\right)\end{array}$ \\
\hline 1 & $\begin{array}{c}4.7^{\mathrm{a}} \\
1.8-7\end{array}$ & $\begin{array}{c}1.09^{\mathrm{a}} \\
0.5-1.8\end{array}$ & $\begin{array}{c}37.5^{\mathrm{a}} \\
16.4-63.6\end{array}$ & $\begin{array}{c}10^{\mathrm{a}} \\
1.5-13\end{array}$ \\
\hline 2 & $\begin{array}{c}1.8^{\mathrm{b}} \\
1.1-2.6\end{array}$ & $\begin{array}{c}0.38^{\mathrm{c}} \\
0.3-0.8\end{array}$ & $\begin{array}{c}20^{\mathrm{b}} \\
12.9-28.2\end{array}$ & $\begin{array}{c}1.5^{\mathrm{b}} \\
0.9-7.5\end{array}$ \\
\hline 3 & $\begin{array}{c}3^{\mathrm{a} \cdot \mathrm{b}} \\
1.3-5\end{array}$ & $\begin{array}{c}0.77^{a . b} \\
0.5-1.6\end{array}$ & $\begin{array}{c}23.8^{\text {a.b }} \\
11.1-39.5\end{array}$ & $\begin{array}{c}4.5^{\mathrm{a} \cdot \mathrm{b}} \\
0.9-12.4\end{array}$ \\
\hline 4 & $\begin{array}{c}2^{\mathrm{b}} \\
1.2-5.5\end{array}$ & $\begin{array}{c}0.5^{b . c} \\
0.4-1\end{array}$ & $\begin{array}{c}19.6^{b} \\
12.9-34.5\end{array}$ & $\begin{array}{c}1.5^{b} \\
0.4-14.8\end{array}$ \\
\hline 5 & $\begin{array}{c}2^{b} \\
1.3^{b}-4.1\end{array}$ & $\begin{array}{l}0.48^{b . c} \\
0.4-1\end{array}$ & $\begin{array}{c}17.6^{\mathrm{b}} \\
11.5-31.8\end{array}$ & $\begin{array}{c}1.5^{\mathrm{b}} \\
0.9-8.1\end{array}$ \\
\hline
\end{tabular}


to point out that no nutrients concentrations were determined. It can be an indication that the impacts observed in the present study are not a consequence of the shrimp farming itself, but they can be related to the management adopted in the enterprise. The inappropriate feed management might have contributed to the accumulation of nutrients immediately below the cages, considering that part of the feed used was not specific to $L$. vannamei, which might have decreased its digestibility and efficiency.

According to $\mathrm{Wu}$ (1995), $23 \%$ of $\mathrm{C}, 21 \%$ of $\mathrm{N}$ and $53 \%$ of $P$ of feed input into the culture system is accumulated on the seabed and the significant impact is normally restricted to within $1 \mathrm{~km}$ from the farm. In shallow waters, with weak currents, solid waste products from aquaculture installations tend to settle on the bottom close to the discharge point (Carrol et al., 2003). Our results are consonant with this information, considering that we observed high concentrations of nutrients below the cages and at the station three ( $200 \mathrm{~m}$ northeast to the cultivation). In the latter, it was observed that the values increased during the period of cultivation, indicating that the high concentrations of nutrients detected on station three are probably related to the shrimp farming.

Finally, our results show that shrimp farming under an inappropriate feed management (using non species-specific diets) can improve significantly the sediment nutrients concentration below the location of the cages. We also obtained an indication that under the studied conditions the raise in the levels of nutrients can reach distances in the range of $200 \mathrm{~m}$.
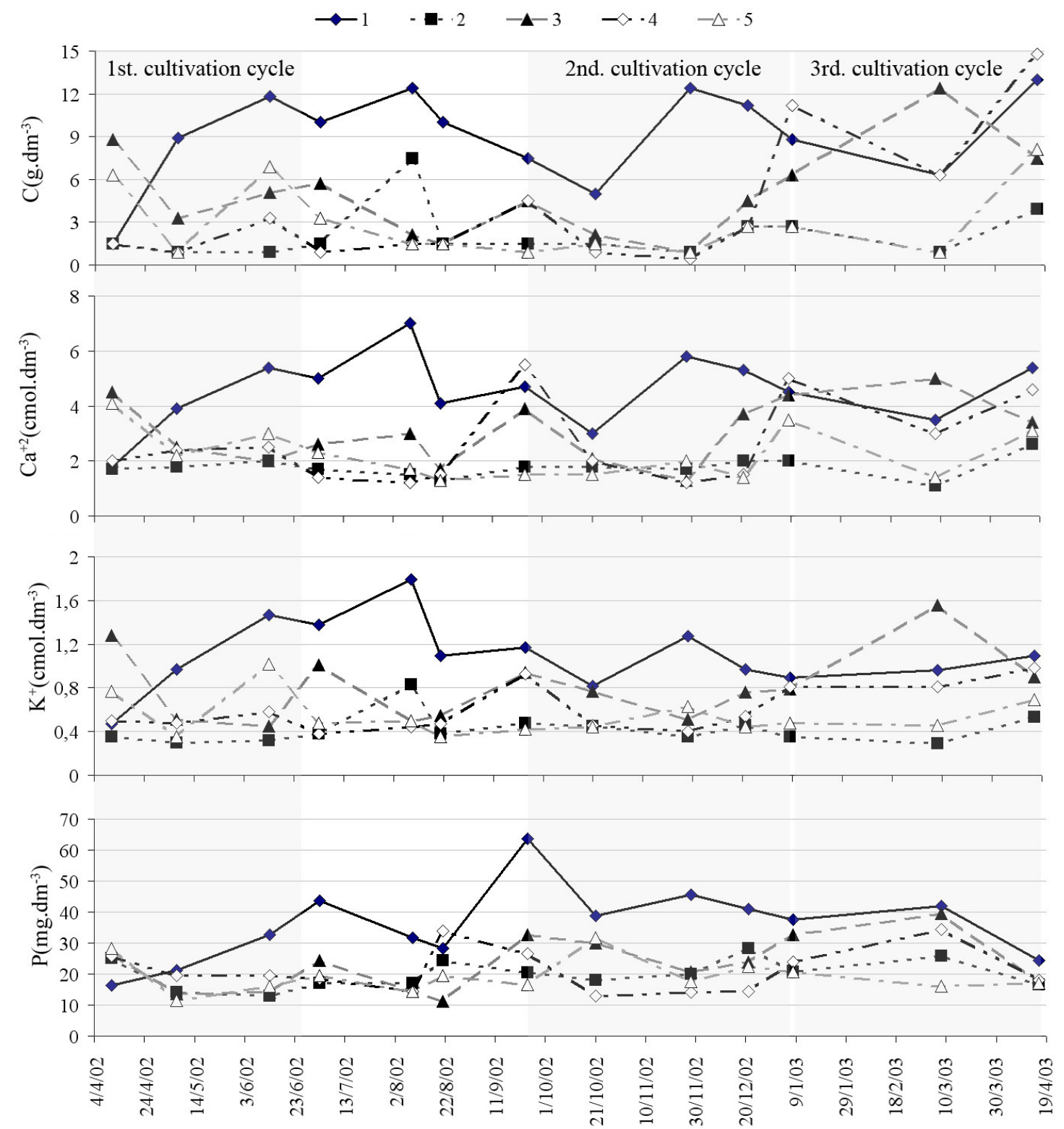

Figure 2 - Temporal variation of sediment quality parameters analyzed from the bottom sediment at the sampling points. Point 1 represents culture unities. 


\section{REFERENCES}

Carroll, M.L.; Cochrane, S.; Fieler, R.; Velvin, R. \& White, P. 2003. Organic enrichment of sediments from salmon farming in Norway: environmental factors, management practices, and monitoring techniques. Aquaculture 226: 165-180.

Halwart, M.; Soto, D. \& Arthur, J.R. 2007. Cage Aquaculture: Regional Reviews and global overview. Food and Agriculture Organization of The United Nations, Rome, 241p.

Islam, S. 2005. Nitrogen and phosphorus budget in coastal and marine cage aquaculture and impacts of effluent loading on ecosystem: review and analysis towards model development. Mar.Poll. Bull. 50(1): 48-61.

Lombardi, J.V.; Marques, H.L.A.; Pereira, R.T.L.; Barreto, O.J.S. \& Paula, E.J. 2006. Cage polyculture of the Pacific white shrimp Litopenaeus vannamei and the Philippines seaweed Kappaphycus alvarezii. Aquaculture 258 (1-4): 412-415.
Paquotte, P.; Chim, L.; Martin, J. L. M.; Lemos, E.; Stern, M. \& Tosta, D. 1998. Intensive culture of shrimp Penaeus vannamei in floating cages: zootechnical, economic and environmental aspects. Aquaculture 164 (1-4): 151-166.

Wasielesky, W. 2000. Cultivo de juvenis do camarão Farfantepenaeus paulensis (Decapoda, Penaeidae) no Estuário da Lagoa dos Patos: Efeitos de parâmetros ambientais e manejo de cultivo. PhD thesis. Departamento de Oceanografia Biológica, Universidade do Rio Grande. 107p.

Wu, R.S.S. 1995. The environmental impact of marine fish culture: Towards a sustainable future. Mar. Poll. Bull. 31 (4-12): 159-166.

Zarain-Herzberg, M.; Fraga, I.; Hernandez-Llamas, A. 2010. Advances in intensifying the cultivation of the shrimp Litopenaeus vannamei in floating cages. Aquaculture 300 (1-4): 87-92.

Submetido: Junho/2012 Revisado: Dezembro/2013 Aceito: Dezembro/2013 